DOI: https://doi.org/10.34069/AI/2021.37.01.18

\title{
Creative methods of noospheric learning through art assets: Case study of authentic education
}

\section{Креативные методы ноосферного обучения средствами искусства: пример аутентичного образования}

Written by:

Alexandra Ovchinnikova ${ }^{62}$ https://orcid.org/0000-0001-5924-1106

Maria Lazareva ${ }^{63}$ https://orcid.org/0000-0003-0101-6306

Tatiana Tarasenko ${ }^{64}$ https://orcid.org/0000-0002-3391-6854

Tatiana Solovieva ${ }^{65}$

https://orcid.org/0000-0001-5523-4937

\begin{abstract}
In this article authors discuss the methodology of evaluating noospheric insights in higher education students through art assets. A very important goal of students' inclusion into the authentic context of ecological education is being achieved. As a result of this study, evaluation criteria were determined, such as imagination, emotionality, originality, abstraction. For the more in-depth development of the evaluation procedure the following methods were used: educational experiment, observation, questionnaires, semantic differential (SD), method of setting the attitude on associative transformation of the object being perceived, creative methods. Authors determined the levels of student's noospheric insights formation (high, above average, average, low) for the following evaluation of correlation between the categories of singular, special and common in students' aesthetical insights. The results, including content and structural, functional components, are described in this article, allowing to connect the process of noosperic insights mastering by students with the authentic context of education.
\end{abstract}

\footnotetext{
${ }^{62}$ Prof., DSc, Lipetsk of State Pedagogical University, Russia.

${ }^{63}$ Docent, DSc, Lipetsk of State Pedagogical University, Russia.

${ }^{64}$ Docent, PhD, Lipetsk of State Pedagogical University, Russia.

${ }^{65}$ Prof., DSc, Lipetsk of State Pedagogical University, Russia.
}

\begin{abstract}
Аннотация
В этой статье авторы обсуждают методологию оценки ноосферных представлений средствами искусства у студентов высших учебных заведений. Решается важнейшая задача приобщения их к экологическому образованию в аутентичном контексте. В результате исследования были определены критерии оценки ноосферных представлений: образность, эмоциональность, оригинальность, абстрагирование. Для более глубокой разработки процедуры оценивания использовались следующие методы: учебный эксперимент, наблюдение, анкетирование, семантический дифференциал (СД), метод установки на ассоциативное претворение воспринимаемого объекта, творческие методы. Авторы определили уровни сформированности ноосферных представлений студентов (высокий, выше среднего, средний, низкий) для последующей оценки корреляции между категориями единичного, особенного и общего в эстетических представлениях студентов. В статье представлены результаты (включающие в себя содержательный и структурно-функциональный компоненты), которые позволили связать процесс усвоения ноосферных представлений у студентов с аутентичным контекстом образования.
\end{abstract}


Key Words: arts and humanities, authentic education, learning, noospheric, cognition strategy.

\section{Introduction}

The problem of formation of the noospheric insights in students correlates with the understanding that a human being, just as all of the live beings, depends on the surrounding environment and the destruction of this environment creates unfavorable ecological situation, resulting from the extermination of the flora and fauna, and atmospheric pollution, which eventually leads to a global noospheric catastrophe. A solution is seen in forming attitudes to the Universe, grounded in love for any form of life on Earth and in Space, and in taking responsibility for the Future of the entire System, the destruction of which will surely result in a global noosperic disaster. Art has a special role in forming of this phenomenon.

Therefore, the purpose of this article is to verify the content of "noospheric insights" definition and to develop a technology of their forming in higher education students through art assets in authentic context

\section{Literature Review}

Scientific literature analysis testifies that in many studies general issues of the noospheric education of students, focused on «humannoosphere" relationships, are elaborately described (Andreoletti \& Torrengo, 2019; Hayn-Leichsenring, 2017; Subetto, 1966; Tolstenko et al., 2019; Vernadsky, 2016); it is proven that art has major influence in individual's noospheric spiritual and value orientation (Asif et al., 2020; Kalahasthi et al., 2017; Klein, 2018); the meaning is defined of cognitive (Feldon et al., 2019; Ovchinnikova et al., 2019; Smirnova \& Georgiadi, 2013; Vi et al., 2017) and aesthetic experience (Hayn-Leichsenring, 2017); of aesthetic creativity in noospheric education (Kozbelt, 2017; Goldshmidt et al., 2018; Maslova, 2013; Vasko et al., 2020). However, noospheric insights as a specific stage of knowledge are not adequately considered (Renn, 2020). Scientists do not attempt to explain this phenomenon, based on the correlation patterns of the categories of singular, special and common in students' cognitive activity. Additionally, technologies of their forming are not developed.
Ключевые слова: искусства и гуманитарные науки, аутентичное образование, обучение, ноосфера, когнитивная стратегия.

Object of study: noospheric insights of higher education students through art assets.

Subject of study: technologies of forming noospheric insights in students through art assets. Study Hypothesis: forming of the noospheric insights in higher education students will be more effective if a technology is developed, based on the correlation of categories of singular, special and common.

In accordance with the purpose and the hypothesis of the study, the following goals were formulated:

1. To clarify the content of the "noospheric insights" definition for higher education students through art assets, based on the categories of singular, special and common;

2. To derive the criterions, methods and levels of forming the noospheric insights in higher education students of art;

3. To develop a technology of forming noospheric insights in higher education students through art assets, based on the abovementioned categories;

4. To validate effectiveness of the technology developed.

Achieving the first goal is tied with the theoretical analysis of the study's main focus, which demonstrated that scientists identify different aspects of the noospheric insights definition. Some authors view it as a level of knowledge, allowing to define the nooshere as a new stage of living matter evolution, as a transit of evolution from its biological phase to social and spiritual (Andreoletti \& Torrengo, 2019; Vernadsky, 2016); other authors see it as an educational activity of students, directed at comprehension of the noospheric ecology from the standpoint of Unity of the human, nature, Universe, space and time (Farr, 2018; Verhavert et al., 2018). As compared to the traditional approaches, we view this definition based on correlation of the singular, special and common and define it as the highest form of sensual comprehension of the world (singular), which itself contains noospheric generalizations (common), interpreted through the creative 
language of art and emotionally-tinted attitude of the individual to life (special).

Singular, as a manifestation of sensual in the rich palette of inter human relationships, depicted in the creative imagery of arts, and based on the experience of real noospheric knowledge about nature, space and human completes the image and makes it whole.

Special is defined in correlation with common and singular and ensures the transition from thesis to antithesis, and from those - to synthesis - depicting the main features of the students' noospheric insights.

Common is characterized as combination of certain groups of objects, indicators, connections, which - with the help of the language of arts - assists with identification of noospheric patterns in learning about the nature, the world, the Universe and Humanity. These categories allow for deeper understanding of the noospheric meaning of the works of art and for taking into account the authentic context of education.

\section{Methodology}

The core method of studying this phenomenon is an educational experiment, conducted with the purpose of learning the cause and effect connections and inclusive of modeling and active impact on the process of forming nooshperic insights with the help of technology. The studies were conducted at Lipetsk State Pedagogical University named after P.P. Tyan-Shansky, and Pskov State University. 229 students participated in this study and altogether 220 respondents were included. The educational experiment included the Defining, Forming and Monitoring stages.

The defining stage took place in September of 2019 and was dedicated to achieving the second goal. The following criteria of forming the noospheric insights in students were identified: imagery, emotionality, originality and abstraction. Their selection is owed to determination of the "noospheric insights" definition and to the singular, special and common categories being represented in it. Corresponding methods were applied to each criterion.

The Imagination criterion is characterized by the ability to distinguish the singular, connected with the bright, picturesque and expressive description and image of the noospheric objects. The methods applied to this criterion were description and interpretation. Students were asked to expressively describe one of the noospheric phenomena reflected in the art work (literature, music, painting); to name the main noospheric ideas in one of the works of M.M. Prishvin, N.K. Roerich, A.N. Skriabin and to interpret them.

The Emotionality criterion was defined as manifestation of intensity of emotions and feelings attributed to the students' personal attitude towards noospheric phenomena a) non verbally, as reflected in emotional state, facial expressions, gestures and intonations of calisthenics (singular and special); b) verbally through emotional evaluations and judgments (common). The methods of observation and C. Osgood's Semantic Differential (SD) (2009) were applied to this criterion.

A set of bipolar scales corresponded to two factors: a) the strength of emotion, б) the adequacy of emotion, each of which were measured on a six point scale. The measure of quality for the strength of emotion was the relation of answers by students who showed strong, bright emotionality ( \pm 3 points), to the total scoring.

$$
\beta_{i}=\frac{n_{i}}{N_{i}}
$$

where $\beta_{i}-$ strength of emotion coefficient, $n_{i}$ - highest points assigned to students, who showed strong emotionality; $N_{i}$ - total of points accumulated by all students.

Nonverbally, the quantitative characteristics of the strength of emotion were measured on a six point scale: $\mathrm{X}_{1}$ (very strong, bright); $\mathrm{X}_{2}$ (medium); $\mathrm{X}_{3}$ (not very strong); $\mathrm{X}_{4}$ (not very weak); $\mathrm{X}_{5}$ (weak); $\mathrm{X}_{6}$ (very weak).

Emotional evaluations and judgments were determined with the help of 12 pairs of adjectives, expressing the emotional condition of students. Student s were asked to compare the paintings of N.K. Roerich, fragments of M.M. Prishvin's Diaries, and a fragment of the symphonic poem "Prometheus" by A.N. Skriabin to a set of indicators, defined by adjectives and answer the question: to what extent is each of the indicators reflected in this work of art? The following descriptors were selected: 


$\begin{array}{llrr}\text { 1. } & \text { Beautiful } & 3+2+1-1-2-3 & \text { Plain } \\ \text { 2. } & \text { Cheerful (glad) } & 3+2+1-1-2-3 & \text { Sad } \\ \text { 3. } & \text { Kind } & 3+2+1-1-2-3 & \text { Evil } \\ \text { 4. } & \text { Bright (ringing) } & 3+2+1-1-2-3 & \text { Dull } \\ \text { 5. } & \text { Light } & 3+2+1-1-2-3 & \text { Dark } \\ \text { 6. } & \text { Quiet } & 3+2+1-1-2-3 & \text { Loud } \\ \text { 7. } & \text { Warm } & 3+2+1-1-2-3 & \text { Cold } \\ \text { 8. } & \text { Soft } & 3+2+1-1-2-3 & \text { Rough } \\ \text { 9. } & \text { Gentle } & 3+2+1-1-2-3 & \text { Abrupt } \\ \text { 10. } & \text { Lightweight } & 3+2+1-1-2-3 & \text { Heavy } \\ \text { 11. } & \text { Pleasant } & 3+2+1-1-2-3 & \text { Unpleasant } \\ \text { 12. } & \text { Amazing } & 3+2+1-1-2-3 & \text { Ordinary }\end{array}$

The measure of adequacy quality was the relation of the highest measure of adequacy in points ( 3 points) to the total scoring.

$$
\beta_{i}=\frac{n_{i}}{N_{i}}
$$

where $\beta_{i}$ - emotion adequacy coefficient, $n_{i}-$ the highest points assigned to students, who showed the highest level of emotion adequacy; $N_{i}$ - total of points accumulated by all students.

The Originality criterion (lat. Originalis - initial) - is the noospherically and aesthetically valuable novelty, originality, distinction, and profoundness of the image created by students, which is manifested in a peculiar selection of facts, uniqueness of the artistic solution, reflecting the student's subjective vision of the world. An E.M. Torshilova's modified method (2018) of "setting the attitude on associative transformation of the object being perceived" was applied to this criterion. Students were asked to paint a magic creature called "Noospherus" and to make up a fairy tale about it. This assignment allowed to characterize the types of creative imagination and to define the connections between functional and sensory indicators. Originality was measured, using formula (3):

$$
W=\frac{n}{N},
$$

where $\mathrm{n}-$ quantity of unique details, associations, images, that no other student repeated; N - total number of students' assignments.

Evaluation scale: ordinary, standard job -0 points; associations and metaphorical images arising in connection with a) objects of inanimate nature -0.25 points; $b$ ) flora and the means of expression used for its depiction - 0.5 points; c) fauna and conveying its emotional condition through expression means - 0.75 points; d) richness of abstract spiritual concepts and values as the unity of audio and visual images 1 point.

The Abstraction criterion is defined by the ability to find the common, to analyze and generalize the noospheric indicators, to define the main noospheric idea of the art work, to comprehend its spiritual, ethical and aesthetical value. The students were offered a fragment of M.M. Prishvin's "The Sun's Treasure Chest", the K. Churlenis "The Sun Sonata" painting, and a fragment of the symphonic suite "Prometeus" by A.N. Skriabin, where they needed to find the main noospheric idea, to define the author's and their own positions and to determine the expressive means which allowed to comprehend it.

Four levels of formation of the noospheric insights in higher education students were defined, based on all criteria: high, above average, average, and low - corresponding to the point scale values of $25-30$ points (8-10) high; 20-24 above average; 15-19 (3-5) average, 10-0 (0-2) low.

Achieving a third goal is connected with the implementation of the formative stage of the experiment, which included the development and implementation of the technology for forming this specific phenomenon. The technology is comprised of the organizational and methodical instruments, and as such - of the combination of psychological and educational predispositions, forms, methods and means of forming the noospheric insights in students. While developing this technology, we assumed that its content must be tied with the criteria of noospheric insights formation in students in accordance with the correlation of singular, special, and common categories. The technology included content, as well as structural and functional components.

A Content component, developed based on the author's program "The interaction of art forms in the noospheric development of students", contains a predisposition to comprehend the singular, special and common categories in the following aspects: 1) organization of the imaginative comprehension of noospheric phenomena from the standpoint of singular; 2) comprehension of the deep meaning of space and time, of the idea of Unity in art, based on the 
foundation of common and special; 3) comprehension of the semantic meaning of nature and Universe in conjunction with the correlation of the singular, special and common.

The first aspect was focused on imaginative and emotional perceptions of noospheric processes and phenomena, as they are reflected in arts from the standpoint of singular, allowing to capture the slightest hues of harmony and beauty of the Universe and to systematize the sensual images of students.

The second aspect implementation was based on abstraction, as the understanding of the deep meaning of the common in comprehension of the noospheric manifestations in arts. While getting to know the works of art, the students, depending on abstraction (common) comprehended the depth of the following noospheric ideas, reflected in the works of art:

1. The Universe is everlasting. The time changes, stars and galactic are born and die, the new ones appear in their place, but nothing changes in the Universe itself, overall (I.A. Bunin, M.M. Prishvin);

2. The inflation of the Universe, much like that of a balloon, which led to the Grand Explosion, as a result of which the matter, the space and the time were created (S. Lem "Solarius");

3. The birth of the Universe as an act of God (J. Haydn " The Creation", J. Bach "Toccata and Fugue in Re Minor", Michelangelo "Creation of Adam");

4. The emergence of the dark energy, or antigravitation, which expands our Universe.

The third aspect is related to the comprehension of the semantic meaning of nature and Universe, based on special in creation of images-symbols. The following noospheric objects that influence the students' personal meaning were selected: Space, and planets of the Solar System. Earth and its elements (fire, air, water), inanimate world, life on Earth (flora, fauna, and underwater world). The world of matter, works of art. Homo Sapiens (singular). Noospheric attributes were selected for those, and they explained the essence of noospheric education: reflection, development, time, space, harmony, contrasts uniformity, movement, symmetry, spirituality, creation, biosphere, creativity (transition from singular to special and common). While studying the works of Russian writer I.A. Bunin the students determined the semantic meaning of a star, using the following images-associations (special, common): "love", "youth", "happiness", "motherland", "godly perfection", "standard of beauty", "varying diversity", "power of life", "religiously-symbolic image", "communication with God", "eternal life", "part of the landscape that allows to accept nature as eternal and constant value". Therefore, the students were able to comprehend the symbolic from the standpoint of spiritual and ethical aesthetic and religious values, pertaining to the affinity of the Godly and Worldly. The following types of interface of the forms of art were used in the experiment: correlative (simultaneous effect of art forms, contributing to creation and analysis of certain emotional and aesthetic situation); integrative (consecutive effect of art forms, selected based on the principle of thematic likeness or contrast); correlative-integrative (simultaneous or consecutive interface of art forms, where the degree of their effect was taken into account).

The structural and functional component of technology included forms, methods and means of forming the noospheric insights in students through art assets in the process of implementation of the author's program.

The main types of practice sessions were collective, group, and individual activities. In the process of implementation of the author's program, the students developed dualcomponent and triple-component integrated lessons for younger students, where they included different degrees of art forms interface; created projects, such as "Noospheric idea of Unity in the works of M.M. Prishvin, J. Bach, M.K. Churlenis", "Time - is it too much or too little". An event of collective creative activity "Beauty and harmony of the Universe" took place, as well as the contests of posters and drawings, such as "Take care of your Planet", and noospheric ecological events, such as "An Hour of the Earth", or field games such as "Where Bunin Lived", "Where Prishvin Lived".

In the process of implementation of the author's program the following active methods of education were used: exploratory (observation), verbal and nonverbal, creative (theory of inventive problem solving, unfinished poem, monotype for description of nature, case method).

Formation of the noospheric insights about time in students, through the assets of arts, in practice required the organization of stimulating objectspace environment, which includes a model of the four seasons of the year, week, days of the 
week, etc), different types of clocks; desktop printed tables ("Happy Hours", "Four Seasons", etc), replicas of paintings (I. Shishkin "Morning in the Pinery", I. Levitan "Autumn Day", A. Savrasov "Sunset over a Marsh", A. Kuindzhi "Moonlight Night on the Dnieper", etc); albums and scrapbooks where seasons were represented, and folk art collections (poems, riddles, proverbs and sayings), etc. They allowed to dialectically comprehend the time from the standpoint of singular, special and common. Therefore, the implementation of this technology allowed forming noospheric insights about nature, as a measure, and about its beauty and harmony, which allow understanding the laws of Space, as the foundation of life on Earth.

Achieving the fourth goal was connected with the implementation of the monitoring stage of the educational experiment. A study was conducted with the purpose of determining the effectiveness of the technology for forming noospheric insights in higher education students through art assets (February, 2020). Scope of study: the content of the noospheric insights based on the singular, special and common. The criteria used (imagination, emotionality, originality, abstraction) were identical to those used in the Defining Stage, and the methods were also corresponding: questionnaires, tests, method of semantic differential (SD) of C. Osgood (2009) and E.M. Torshilova's method (2018) of setting the attitude on associative transformation of the object being perceived. In the process of the study experimental and theoretical (model) characteristics were compared to determine the patterns of forming the noospheric insights in students, based on the categories of singular, special and common.

\section{Results and Discussion}

The results analysis at the Defining Stage of the experiment (pre-education) demonstrated that $4.5 \%$ of students were at high level for the Imagination criterion. Their responses contained distinct picturesque and expressive descriptions of the idea that nature, Space, Universe and time in art are united as one. They used nine or more indicators of expressiveness and transitioned from the singular to common. $10.9 \%$ of students were at the above average level. Their imaginative perception differentiated by $6-8$ attributes; the expressiveness of the attributes was reflective of their personal experience. A strong manifestation of the singular was observed. $46.3 \%$ of students demonstrated average levels of formation of noospheric insights. They identified 3-5 expressive indicators; singular was fragmented, their responses often correlated with everyday life impressions and were very generic. $36.2 \%$ students were at the low level. Their responses were monotonous and schematic in their image description. The singular was reflected in identification of 1-2 expressive indicators of the object (Table 1).

Table 1.

Levels and criteria of formation of noospheric insights in higher education students before and after being educated. Source: the author.

\begin{tabular}{|c|c|c|c|c|c|c|c|c|}
\hline \multirow{3}{*}{ Levels } & \multicolumn{8}{|c|}{ Criteria } \\
\hline & \multicolumn{2}{|c|}{ Imagination } & \multicolumn{2}{|c|}{ Emotionality } & \multicolumn{2}{|c|}{ Originality } & \multicolumn{2}{|c|}{ Abstraction } \\
\hline & Before & After & Before & After & Before & After & Before & After \\
\hline High & 4.5 & 34.6 & 9.1 & 23.7 & 3.6 & 13.5 & 4.5 & 16.9 \\
\hline $\begin{array}{l}\text { Above } \\
\text { average }\end{array}$ & 10.9 & 43.4 & 13.6 & 34.0 & 12.7 & 43.4 & 12.7 & 43.4 \\
\hline Average & 43.6 & 12.3 & 41.8 & 47.7 & 40 & 28.2 & 57.7 & 28.2 \\
\hline Low & 36.2 & 21.9 & 35.5 & 10.0 & 43.7 & 14.9 & 25.1 & 11.5 \\
\hline
\end{tabular}

$9.1 \%$ of students demonstrated high emotionality; $13.6 \%$ - above average; $41.8 \%$ average; $35.5 \%$ - low.
Table 2 summarizes the results of external expressions of emotionality, related to the identification of the singular, by emotion strength and adequacy. 
Table 2.

Frequency of students' emotion strength and adequacy, by strength of emotion. Source: the author.

\begin{tabular}{|c|c|c|c|c|c|c|c|c|c|c|}
\hline \multicolumn{11}{|c|}{ Frequency of Selection } \\
\hline \multicolumn{4}{|c|}{ Emotion Strength } & \multicolumn{7}{|c|}{ Adequacy and Inadequacy of Emotion } \\
\hline 3 & 2 & 1 & Total & +3 & +2 & +1 & -1 & -2 & -3 & Total \\
\hline 316 & 604 & 388 & 1308 & 192 & 406 & 220 & 169 & 199 & 122 & 1308 \\
\hline
\end{tabular}

Using the data from Table 2 in formula (1):

$$
\beta_{i}=\frac{n_{i}}{N_{i}}
$$

derived $\beta_{\text {strength }}=316 / 1308=0,24 ; \beta$ adequacy $=$ $169 / 1308=0,13$.

According to the study results, the "originality" criterion (Table 1), is at high level in $3.6 \%$ of students; $12.7 \%$ - above average, $40 \%$ average, $43.7 \%$ - low. It is noted that originality, as manifestation of the special, by association indicator (E.M. Torshilova's method) manifested itself in connection with the inanimate world objects (such as "Space", "Sun", "Stars") in $46.8 \%$ of association cases; in connection with the fauna (for example, "planets remind us of mysterious animals") in $37.7 \%$; as richness of the abstract spiritual definitions and values (for example, "compassion", "humanity”, "eternity") in $15.6 \%$. Of those, the most associations emerged by form, fewer - by color, in rare cases - by motion.

Abstraction, as the ability to identify the common, to analyze and generalize the noospheric indicators, to identify the main noospheric idea of the artwork, was also evaluated on four levels: $4.5 \%$ of students ranked at high, $12.7 \%$ - above average, $57.7 \%$ average, $25.1 \%$ - low.

Hence, the formation of noospheric insights in students through art assets by all criteria, during the Defining Stage of the experiment was at average and low levels.

After the forming stage, involving the technology implementation, a monitoring stage was conducted, and the results are depicted in Table 1. They demonstrate that, the criterion of Imagination was at high level in $34.6 \%$ of students and the results increased 7.7 times; $43.4 \%$ were above average and the results increased 2.6 times, $12.3 \%$ were average and the results decreased 2.6 times; $21.9 \%$ were low and the results decreased 1.6 times.
The expression of emotionality was at high level in $23.7 \%$, results increased 3 times, $34.0 \%-$ above average, results increased 2.5 times; $47.7 \%$ - average, results decreased 1.1 times; $10.0 \%$ - low, results decreased 3.5 times.

Originality was at high level in $13.5 \%$ of students, results increased 3.7 times; $43.4 \%$ above average, results increased 3.4 times, $28.2 \%$ - average, results decreased 1.4 times; $14.9 \%$ - low, results decreased 2.9 times.

Abstraction was at high level in $16.9 \%$ of students, results increased 3.7 times; $43.4 \%$ above average, results increased 3.4 times; $28.2 \%$ - average, results decreased 7 times; $11.5 \%$ - low, results decreased 2.2 times.

Thus, significant changes, by all criteria, happened at high, above average and low levels, which testifies to the effectiveness of the technology developed for forming the noospheric insights in higher education students through art assets, based on categories of singular, special and common.

The genesis of the study subject allowed to clarify the content of the noospheric insights in higher education students, based on categories of singular, special and common and to consider this phenomenon as the highest form of sensual reflection of the world, containing in itself the opportunity for noospheric generalizations, viewed through the creative language of artwork and through emotionally tinted attitude of the individual to life. Their specifics were defined by the understanding of the idea of Unity of the human and nature, world, Space. As compared to other studies (Fomina et al. 2019; Lavreneva, 2017; Subetto, 1966), new developments were as follows: a) the content of noospheric insights in students was defined, based on the correlation of singular, special, and common; b) new knowledge was derived about their formation through art assets; c) a technology was developed for forming the noospheric insights in students through art assets; d) criteria, methods and levels of noospheric insights formation in higher education students were defined. 
The results derived during the Defining stage of the experiment allow to conclude that they depend on the ability of students to: a) imaginatively and expressively describe noospheric objects and phenomena, characterize personal attitude of the student to the noospheric phenomena, in connection with the intensity of emotions and feelings expression, based on identification of the singular; b) create unique, bright images, connected with the uniqueness of the artistic solution and the subjective vision of the issue by the student, based on the identification of the special; c) analyze and generalize the indicators of noospherism in arts, identify the main idea of the artwork, based on the manifestations of the common. The following criteria were identified: imagination, emotionality, originality, abstraction; corresponding methods were used and levels were defined (high, above average, average, low), which provided an opportunity to deeply and comprehensively study the noospheric insights of the students. As part of the experiment, patterns of correlation of the singular, special and common were identified in noospheric insights of the students. Mostly, the students identified the singular, somewhat more common and least special. This is due to their unpreparedness to systematization and generalization of the sensual images in art, to independent creative and research activity and to stereotypical thought process.

The criteria and levels identified allowed developing the technology for formation of noospheric insights in students, which allowed to purposefully managing the rational methods of students' preparation for the understanding of noospheric categories, processes and phenomena in art, based on the correlation of singular, special and common. To encourage the more effective formation of the noospheric insights in students, the content was defined for the structural and functional component of the technology and the following directions were determined: 1) organization of the process of the imaginative comprehension of noospheric phenomena, defining the idea of Unity; 2) realization of the meaningful importance of the Space and time in art; 3) comprehension of semantic meaning of nature and Universe.

Their implementation assumed deeper content of the author's educational course in conjunction with: a) the understanding of the idea of Unity and harmony in human's becoming one with nature; b) the ability to find and implement this idea in the process of art forms' integration; c) to define and reflect the conceptual and semantic importance of the images, while using the correlative and integrative, as well as correlative-integrative types of art forms interface. In the process of implementation of these directions, students faced difficulties with constructing the triple-component lessons, pertaining to the interaction and integration of art forms. To overcome these difficulties, we used collective, group and individual forms of activities, active research and creative methods.

The effectiveness of this technology is proven by the results of the study represented in Table 1 . Therefore, the hypothesis is also proven, and the goals are achieved.

\section{Conclusions}

The analysis of scientific literature testifies to the relevance of the issue of forming the noospheric insights in higher education students. At the same time, the content of this definition, based on the correlation of singular, special and common categories in higher education students, require detailed research. From these standpoints, we define the noospheric insights as a certain step in comprehension, based on the sensual reflection of the world (singular), through the creative image of art (common) and emotionally tinted attitude of the individual, revealing the spiritual, cultural and creative values (special), from the standpoint of Unity of the human with nature and in allencompassing richness of the social, spiritual and ethical relations of the human with the world, Space, Universe and time in art.

With the goal of defining the level of noospheric insights formation in higher education students, based on correlation of categories of the singular, special and common, the following criteria (imagination, emotionality, originality, abstraction) were identified, as well as method corresponding to them (experiment, questionnaire, interpretation, Semantic Differential (SD) method of C. Osgood, an E.M. Torshilova's method of setting the attitude on associative transformation of the object being perceived. All of these allowed determining and characterizing four levels: high, above average, average and low.

With the help of mathematical methods (weighting coefficients) it was proven that the technology, inclusive of the content, structural and functional components, is effective and allows managing the process of noospheric insights formation holistically, in students, through art assets, as well as forecasting the 
results received. Therefore the hypothesis is proven, and goals are achieved.

In this article aspects of noospheric insights formation were considered, in the process of implementation of technology for student education. In the future, a study of these phenomenon characteristics is planned, based on researching their motivations, requirements and learning aspects, as part of the educational process of the higher education and distant learning. Practically, it is planned to study the opportunities of using the technology and pedagogic conditions in the educational process of students in various areas of training.

\section{Acknowledgements}

In closing, the authors wish to express sincere gratitude to the Department and Administration of the Lipetsk State Pedagogical University named after P.P. Semionov Tyan-Shansky, and Lipetsk Municipal school No. 24 named after M.B. Rakovsky, for providing the basis for this study.

\section{Bibliographic references}

Andreoletti, G., \& Torrengo, G. (2019). Time travel and the immutability of the past within Btheoretical models. Philosophia, 47(4), 1011-1021.

Asif, T., Guangming, O., Haider, M.A., Colomer, J., Kayani, S., \& Ul Amin, N. (2020). Moral education for sustainable development: Comparison of university teachers' perceptions in China and Pakistan. Sustainability, 12, 3014. Farr, K. (2018). Analyzing the elements of art. Five ways to think about space. The New York Times Company. Retrieved from https://www.nytimes.com/2018/01/03/learning/l esson-plans/analyzing-the-elements-of-art-fiveways-to-think-about-space.html

Feldon, D.F., Callan, Ju.G., Juth, S., \& Soojeong, Je. (2019). Cognitive load as motivational cost. Educational Psychology Review, 31(5), 319-337.

Fomina, N., Pechko, L., \& Koptseva, T. (2019). Development of artistic giftedness in school students within the framework of Russian education (in the 1920-40s). International Journal of Innovative Technology and Exploring Engineering, 9(1), 4032-4036.

Goldshmidt, E.S., Gritskevich, T.I., Mesheryakova, S.M., \& Cherepanov, A.Y. (2018). Concept of noospheric education: innovative methods for developing personal cognitive strategies. European Proceedings of Social and Behavioural Sciences, 35, 383-394.
Hayn-Leichsenring, G.U. (2017). The ambiguity of artworks. A guideline for empirical aesthetics research with artworks as stimuli. Frontiers in Psychology, 8, 1857.

Kalahasthi, R., Bhuptani, P.H., \& Kapoor, H. (2017). An analysis of thoughts, behaviours, and emotions in daily decision-making. Psychological Studies, 62(4), 409-420.

Klein, S.R. (2018). Coming to our senses: Everyday landscapes, aesthetics, and transformative learning. Journal of Transformative Education, 16(1), 3-16.

Kozbelt, A. (2017). Tensions in naturalistic, evolutionary explanations of aesthetic reception and production. New Ideas in Psychology, 47, 113-120.

Lavreneva, O. (2017). Nicholas Roerich's notebook sheets - space essays. Studia Litteraria Universitatis Iagellonicae Cracoviensis, 12(4), 289-297.

Maslova, N.V. (2013). Noospheric education: methodology, technology, tools. Herald of Ecological Education in Russia, 67(1), 23-26.

Osgood, C.E. (2009). Semantic differential technique in the comparative study of cultures. American Anthropologist, 66(3), 171-200.

Ovchinnikova, A.Zh., Lazarev, B.N., Lazareva, M.V., \& Tigrova, I.V. (2019). El desarrollo del pensamiento lógico en alumnos jóvenes a través del aprendizaje basado en proyectos [The development of logical thinking in junior pupils through project-based learning]. Revista Dilemas Contemporáneos: Educación, Política y Valores, 30, 88. Retrieved from https://www.dilemascontemporaneoseducacionp oliticayvalores.com/index.php/dilemas/article/vi ew/1116/257

Renn, J. (2020). Evolution of Knowledge: Rethinking Science for the Anthropocene. Princeton: Princeton Univ. Press.

Smirnova, E., \& Georgiadi, V. (2013). Dialogic pedagogy in teaching the disciplines in the higher education system. World Applied Sciences Journal, 24(7), 850-857.

Subetto, A.I. (1966). Bertolt Brecht and the dialectic of tradition. Forum for Modern Language Studies, II(2), 123-140.

Tolstenko, A., Baltovskij, L., \& Radikov, I. (2019). Chance of civic education in Russia. SAGE Open, 9(3), 1-19.

Torshilova, E.M., \& Boyakova, E.V. (2018). Diagnosing art appreciation of children between the ages of four and nine years. International Journal of Engineering and Technology, 7(4), 564-568.

Vasko, R., Korolyova, A., Tolcheyeva, T., \& Kapranov, Y. (2020). Human language as a natural artifact of planetary-noospheric mind: coevolutionary-macromutational 
reinterpretation. Amazonia Investiga, 9(34), 17-23.

https://amazoniainvestiga.info/index.php/amazo nia/article/view/1491

Verhavert, S., Wagemans, J., \& Augustin, M.D. (2018). Beauty in the blink of an eye: The time course of aesthetic experiences. British Journal of Psychology, 109(1), 63-84.
Vernadsky, V.I. (2016). Philosophy of Science. Selected Works. Moscow: Yurait. (in Russian) Vi, C.T., Ablart, D., Gatti, E., Velasco, C., \& Obrist, M. (2017). Not just seeing, but also feeling art: Mid-air haptic experiences integrated in a multisensory art exhibition. International Journal of Human-Computer Studies, 108, 1-14. 